\title{
A leitura na universidade: ideias circulantes
}

\section{Reading at university: circulating ideas}

\section{La lectura en la universidad: ideas circulantes}

\author{
Lucinea Aparecida de Rezende* \\ Sandra Aparecida Pires Franco** \\ Cristina Nalon de Araújo ${ }^{* * *}$
}

\begin{abstract}
Resumo: Neste artigo, são apresentados dados acerca da leitura na universidade, com o objetivo de (re)avaliar o ensino da leitura, por meio das ideias de senso comum que perpassam as suas práticas. A pesquisa teve duas fases e contou com participantes das áreas de Ciências Biológicas e Exatas, e, prioritariamente, com alunos de quatro cursos de Ciências Humanas. $\mathrm{Na}$ fase I, foram mapeadas as ideias circulantes de senso comum acerca da leitura, com vistas à construção de núcleos temáticos a serem explorados na fase II. Nesta última, os blocos de questões tiveram como temas: leitura; leitura e escrita; internet; fontes diversificadas; leitura hoje e há vinte anos e implicação dos métodos nos processos de alfabetização. A metodologia, predominantemente qualitativa, tem caráter exploratório, com elementos da análise do discurso. Os resultados indicam que a universidade desempenha importante papel no trato com a leitura, e, por outro lado, existem espaços a serem ocupados por ela, o que poderia levar a mais amplas contribuições na formação contínua de leitores.
\end{abstract}

Palavras-chave: Leitura na universidade. Formação do leitor. Ideias circulantes acerca da leitura.

Abstract: This paper presents data about reading at university, with the aim to (re) evaluate reading teaching, through the common sense ideas which permeate this practice. The study comprised two phases and had participants from Biological and Exact Sciences, and involved especially students from four courses of Human Sciences. In phase I, the common sense circulating ideas about reading were mapped, aiming to build theme nuclei to be explored in phase II. In the latter, the blocks of questions covered themes such as: reading, reading and writing, internet, diversified sources,

\footnotetext{
* Professora do Programa de Pós-Graduação em Educação da Universidade Estadual de Londrina - UEL. E-mail: <lucinearezende@gmail.com>

** Professora do Programa de Pós-Graduação em Educação da Universidade Estadual de Londrina - UEL. E-mail: <sandrafranco26@hotmail.com>

*** Mestranda do Programa de Pós-Graduação em Educação da Universidade Estadual de Londrina - UEL. E-mail: <cristina.n.araujo@hotmail.com>
} 
reading nowadays and 20 years ago and the implication of methods in the reading/ writing learning processes. The methodology, mainly qualitative, has an exploratory character, with elements of discourse analysis. Results indicate that the university plays an important role when it comes to reading, and, on the other hand, there are spaces to be occupied by it, which could lead to further contribution to the continuous development of readers.

Keywords: Reading at university. Reader development. Circulating ideas about reading.

Resumen: En este artículo, se presentan datos acerca de la lectura en la universidad, con el objetivo de (re)evaluar la enseñanza de la lectura, por medio de las ideas de sentido común que se ven presentes en sus prácticas. La investigación tuvo dos fases y contó con participantes de áreas como Ciencias Biológicas y Exactas, y, prioritariamente, con estudiantes de cuatro carreras de Ciencias Humanas. En la fase I, se buscó mapear las ideas circulantes de sentido común acerca de la lectura, con vistas a la construcción de núcleos temáticos a explorar en la fase II. En esta última, los bloques de cuestiones tuvieron como temas: lectura; lectura y escrita; internet; fuentes diversificadas; lectura hoy y hace veinte años e implicación de los métodos en los procesos de alfabetización. La metodología, predominantemente cualitativa, tiene carácter exploratorio, con elementos del análisis del discurso. Los resultados indican que la universidad desempeña importante papel en el trato con la lectura, y que, por otro lado, hay espacios todavía por ocupar, lo que podría llevar a mejores contribuciones en la formación continua de lectores.

Palabras clave: Lectura en la universidad. Formación del lector. Ideas circulantes acerca de la lectura.

\section{Introdução}

Neste texto, a leitura é compreendida como meio de ação ou interação, visto que nos constituímos a partir de relações concretas com o real, que, à primeira vista, nos aparece de forma difusa. Desta forma, o real é tomado como ponto de partida, tendo-se como alvo sua superação, já que só é possível alcançar um concreto pensado, partindo, dialeticamente, de um concreto caótico. Afinal, "O homem sempre vê mais do que aquilo que percebe imediatamente" (KOSIK, 1976 , p. 24 e 30$)$.

Essas ideias vão ao encontro do que expressou Bakhtin (1992), ao colocar em primeiro lugar "a questão dos dados reais da linguística, da natureza real dos fatos da língua" e defender que "a palavra é a arena onde se confrontam valores sociais contraditórios" (YAGUELLO, 1992, p. 14), bem como da concepção de linguagem explicitada por Koch (2008, p. 7-8),

[...] como 'atividade', como 'forma de ação', ação inter-individual finalisticamente orientada; como lugar de 'interação' que possibilita aos membros de uma sociedade a prática dos mais diversos tipos de atos, que vão exigir dos 
semelhantes reações e/ou comprometimentos, levando ao estabelecimento de vínculos e compromissos anteriormente inexistentes.

Com esses pressupostos, o foco do estudo ora relatado são as "manifestações linguísticas produzidas por indivíduos concretos em situações concretas, sob determinadas condições de produção" (KOCK, 2008, p. 9). Os enunciados têm implicações e estas nos interessam no tocante à assunção e difusão de ideias circulantes entre professores, alunos e seus pais ou outros familiares, e equipes pedagógico-administrativas, no que diz respeito ao ensino da leitura. A concepção teórica assumida tem presente que a língua está associada à sua utilização e acontece em forma de enunciados, sejam eles orais e/ou escritos. Os enunciados partem de pessoas pertencentes a diversas esferas da atividade humana, refletindo "as condições e finalidades de cada uma dessas esferas" (BAKHTIN, 1997, p. 279).

\section{Ponto de partida}

A pesquisa foi desenvolvida a partir dos escritos de Jacques e Éliana Fijalkow (2003): Idées reçes - La Lecture, traduzido ${ }^{1}$ por Ideias circulantes acerca da leitura. Os autores afirmam que as ideias circulantes são tenazes. Nascem do bom senso popular (senso comum) ao longo do tempo e se fixam em frases caricaturais de opiniões (FIJALKOW; FIJALKOW, p. 7, tradução livre). Compreender essas ideias pode auxiliar a superá-las.

Para Jacques e Éliana Fijalkow (2003), inspiradores desse estudo, nas décadas de 80 e 90, consideradas por eles em suas pesquisas, as estatísticas francesas apontavam para o grande número de televisores nas residências e um número bem mais restrito de livros lidos pelas pessoas a cada mês. Situação esta não muito diferente da atual, pois a pesquisa Retratos da Leitura no Brasil, publicada em 2012, revela que o brasileiro lê, em média, 4 livros por ano, dos quais 2,1 (dois vírgula um) são lidos inteiros (RETRATOS DA LEITURA NO BRASIL, 2012).

Jacques e Éliana Fijalkow (2003) indicam, nesse contexto, ideias de senso comum, que então circulavam, tais como: as pessoas não leem mais, elas só veem TV; o computador vai substituir o livro; o método global é responsável pelas dificuldades de leitura dos alunos. Vê-se que essas ideias continuam presentes em nosso dia a dia de trabalho e isso contribuiu como sinalização para procurar saber o que pode ser mais bem conhecido a respeito delas, com vistas a superá-las.

Os autores já citados afirmam que despir as ideias circulantes ligadas à leitura para poder superá-las implica distinguir três situações: a realidade da

${ }^{1}$ Tradução livre das autoras. 
leitura, os discursos dos pesquisadores acerca desse tema e as mídias - veículos privilegiados das ideias circulantes. De um lado, estão os discursos científicos pretensamente neutros e, de outro, os que circulam livremente como discursos midiáticos. Essas três situações perpassam este estudo.

Delineado o contexto, enfatizada "a realidade da leitura", como no referencial teórico indicado, consideraram-se os pressupostos:

a) existem em circulação no meio acadêmico ideias equivocadas sobre leitura;

b) ideias equivocadas sobre leitura contribuem para manter o status quo nesses campos.

A partir desse delineamento, configurou-se o problema a ser investigado: identificadas e desfeitas ideias equivocadas acerca da leitura entre acadêmicos, parte dos obstáculos ao seu ensino e aprendizagem poderá ser superada? Como objetivo geral, intentou-se (re)avaliar o ensino da leitura por meio das ideias de senso comum, que perpassam as suas práticas.

$\mathrm{Na}$ leitura, consciente ou inconscientemente, utilizamos estratégias ${ }^{2}$ que nos possibilitam acessar o texto e, dessa forma, são mobilizados diferentes conhecimentos do leitor, ou seja, seus conhecimentos prévios e capacidade de estabelecer relações de informações, destacando-se o conhecimento de mundo, o que inclui o saber linguístico, enciclopédico e interacional.

Os conhecimentos linguísticos referem-se aos conhecimentos da língua e correspondem a itens lexicais, estruturas sintáticas, contemplados no uso dessa língua. Esses elementos se manifestam na superfície do texto e são responsáveis pela ativação do conhecimento de mundo, arquivado na memória dos usuários (leitores e escritores). O conhecimento linguístico é importante para a leitura e a escrita; contudo, ele é apenas parte do que usamos para interpretar e produzir um texto, pois esse nível se processa em conjugação com os outros.

Os conhecimentos de mundo remetem a conhecimentos armazenados na memória de cada indivíduo, sob a forma de esquemas ${ }^{3}$, que são estruturas

\footnotetext{
${ }^{2}$ Se as estratégias de leitura são procedimentos e os procedimentos são conteúdos de ensino, então é preciso ensinar estratégias para a compreensão de textos. Estas não amadurecem, nem se desenvolvem, nem emergem, nem aparecem. Ensinam-se - ou não se ensinam - e se aprendem - ou não se aprendem. Se considerarmos que as estratégias de leitura são procedimentos de ordem elevada que envolvem o cognitivo e o metacognitivo, no ensino, podem ser tratadas como técnicas precisas, receitas infalíveis ou habilidades específicas. O que caracteriza a mentalidade estratégica é sua capacidade de representar e analisar os problemas e a flexibilidade para encontrar soluções. Por isso, ao ensinar estratégias de compreensão leitora, entre os alunos, deve predominar a construção e o uso de procedimentos de tipo geral, que possam ser transferidos sem maiores dificuldades para situações de leituras múltiplas e variadas. (SOLÉ, Isabel. Estratégias de leitura. 6. ed. Porto Alegre: Artmed, 1998, p. 70).

${ }^{3} \mathrm{O}$ termo esquema veio da psicologia, mais diretamente de Bartlett, que estudou a memória e em sua obra Remembering (1932), o termo se solidificou (RUMELHART, 1981).
} 
cognitivas registradas em unidades de informação na memória de longo prazo ${ }^{4}$. Isso quer dizer que, para compreender o mundo, é preciso que se tenha dentro de si uma representação dele. Os esquemas formam-se a partir de experiências socioculturais dos indivíduos, uma vez que todos os seres humanos praticam o ato da interação nesses contextos. Se a interação entre os indivíduos não acaba nunca, então os esquemas estão sempre crescendo e se modificando, a fim de que seja possível armazenar novas experiências e novas leituras sejam feitas. É com base em tais modelos, por exemplo, que se levantam hipóteses, produzemse inferências capazes de preencher as lacunas ou potencialidades dos textos. Assim, é mais fácil construir sentidos para um texto quanto mais informações estiverem presentes em nossa memória acerca de determinado tema. Logo, à medida que o leitor vai avançando em novas leituras no decorrer de suas experiências, os seus modos de organizar o conhecimento (esquemas) vão sendo modificados. Sendo assim, sua capacidade interpretativa se amplia à proporção que seus esquemas vão sendo aumentados.

O conhecimento interacional, de acordo com Koch e Elias (2006), prevê os seguintes conhecimentos: o ilocucional, que nos permite reconhecer os objetivos do produtor do texto; o comunicacional, que diz respeito à quantidade de informação necessária, seleção da variante linguística adequada à situação de interação e adequação do gênero textual; e o metacomunicativo, ou seja, aquele que permite ao locutor assegurar a compreensão do texto e conseguir a aceitação pelo parceiro dos objetivos com que é produzido o texto.

No momento da leitura, o leitor é alicerçado pelos conhecimentos prévios, conforme Lajolo (1997, p. 53): “ao seguir o texto, o leitor pronuncia seu sentido por meio de um método profundamente emaranhado de significações aprendidas, convenções sociais, leituras anteriores, experiências individuais e gosto pessoal". A interação do texto frente aos conhecimentos prévios do leitor permite a construção de sentidos, novos conhecimentos, que ampliam os quadros de referência do leitor. Devido a esses elementos e à sua competência comunicativa, o leitor interfere no texto que lê, podendo privilegiar ou não certos trechos de um texto que condizem ou não com a sua visão de mundo e com seus dados de experiência. Dessa forma, um texto terá leituras diferentes por parte de leitores diferentes, ou mesmo da parte de um único leitor em momentos diferentes, dependendo de seu universo de experiências. A propósito, cabe lembrar Manguel (1997, p. 54), visto que o autor aponta para a subjetivade do ato de ler, presente em diferentes leitores: "ler, então, não é um processo automático de capturar um texto como um papel fotossensível captura a luz, mas um processo de reconstrução desconcertante, labiríntico, comum e, contudo, pessoal"

\footnotetext{
${ }^{4}$ Memória de longo prazo consiste em informações que temos permanentemente mais disponíveis, com capacidade ilimitada.
} 


\section{Metodologia}

O estudo foi desenvolvido em uma universidade de grande porte no Norte do Paraná, teve duração de 3 anos (2009 a 2012) e contou, na primeira fase, com sujeitos participantes dos cursos indicados no quadro 1 , adiante, em número de quatro para cada grupo, a saber: professores (4); equipes pedagógicoadministrativas (4); pais ou familiares de alunos (4); estes últimos, também em número de quatro ${ }^{5}$. Dessa forma, buscou-se o sentido da palavra (dos dizeres) em seu contexto (BAKHTIN, 1992). Na segunda fase do estudo, só os alunos participaram.

A seleção dos cursos na fase II abrangeu: Pedagogia $(14)^{6}$, Letras Inglês ${ }^{7}$ A (11) e B (2), Espanhol (5) e Ciências Sociais (12) e está, portanto, no âmbito das Ciências Humanas. O recrutamento dos participantes da pesquisa foi feito de maneira aleatória, de acordo com a manifestação do desejo do público-alvo em participar, após convite direto, feito pelas pesquisadoras. Trata-se de estudo de caráter predominantemente qualitativo, seguindo a vertente exploratória, com elementos que permeiam a análise do discurso (LOZANO; PEÑA-MARIN; ABRIL, 2002).

Quadro 1 - Quantificação dos participantes da fase I

\begin{tabular}{|c|c|c|c|c|c|}
\hline $\mathbf{N}^{\mathbf{0}}$ & Curso & Professor & Aluno & Coordenador & Família \\
\hline 1 & Fisioterapia & 4 & 5 & 4 & 5 \\
\hline 2 & Medicina & 4 & 4 & 4 & 4 \\
\hline 3 & Pedagogia & 4 & 3 & 4 & 5 \\
\hline 4 & Matemática & 4 & 4 & 4 & 4 \\
\hline 5 & Biologia & 7 & 4 & 0 & 0 \\
\hline 6 & Ciências Sociais & 2 & 6 & 1 & 0 \\
\hline 7 & Física & 6 & 10 & 1 & 0 \\
\hline 8 & Letras & 5 & 6 & 1 & 0 \\
\hline 9 & Química & 7 & 8 & 1 & 0 \\
\hline $\begin{array}{c}\text { Total de } \\
\text { participantes }\end{array}$ & 9 cursos & 43 & 50 & 20 & 18 \\
\hline
\end{tabular}

Fonte: As autoras.

Como parte dos procedimentos de coleta de dados, com o intuito de recolher ideias circulantes (idées reçues - IR) de senso comum, que perpassam as temáticas/atividades de leitura. Em um primeiro momento, foram feitas perguntas

\footnotetext{
${ }^{5}$ Ainda que se tenha definido, a priori, que o número participantes de cada grupo da pesquisa seria 4 , esse número variou para mais ou um pouco menos, visto que em algumas classes mais alunos pediram para participar da pesquisa e, por outro lado, às vezes, não se conseguiram participantes em número de 4 , quer seja no caso de pais de alunos, quer seja no caso de equipes pedagógico-administrativas. Conferir no quadro 01.

${ }^{6}$ Número de participantes.

${ }^{7}$ Duas turmas de Letras Inglês.
} 
aos participantes do Projeto (Fase I). Pediu-se para eles responderem às questões a seguir, de preferência numa frase (idées reçues), escolhendo entre a questão 1a e 1b (restringir-se a uma questão na resposta), conforme pensavam/pensam que os estudantes são ou não bons leitores, de maneira que não houvesse indução nas respostas.

- 1 a - Por que os estudantes são bons leitores?

- 1 b - Por que os estudantes não são bons leitores?

Ainda que se tenha pedido para responderem a uma das duas questões, conforme seus pontos de vista, alguns participantes responderam às duas, diferentemente do que fora indicado pelas pesquisadoras (restringir-se à questão 1a ou 1b).

Em um segundo momento, outra coleta de dados de campo foi feita, como complemento da primeira. Foram destacados, desta feita (Fase II), os núcleos temáticos que perpassavam as respostas encontradas na primeira fase da pesquisa e que nortearam a reelaboração de questões formuladas previamente e, após, revistas à luz dos dados coletados no primeiro momento da pesquisa.

Nessa segunda coleta de dados (Fase II, contendo 6 blocos de questões), voltada exclusivamente aos alunos, foi perguntado, no Bloco I, denominado Leitura, acerca da frequência com que as leituras são feitas; o tempo, em média, dedicado a elas a cada vez que se lê; qual(is) o(s) gênero(s) literário(s) é(são) lido(s) com maior frequência; se já houve vontade de adquirir um livro, mas isso não foi feito, e qual a razão atribuída à não aquisição; se o aluno vai a livrarias quando deseja comprar livros; se compra pela Internet ou outro meio; se considera que a universidade contribui para tornar o aluno bom leitor; se a universidade proporciona espaço de incentivo à leitura; e, no caso de haver esse espaço de incentivo à leitura, se o estudante pensa que ele é bem aproveitado pelos professores. Foi pedido também que fosse comentada a frase de Flaubert "Leia para viver", com vistas a conhecer-se melhor as ideias que os alunos detêm acerca da leitura.

No Bloco II, denominado Leitura e Escrita (neste texto, só foi considerada a leitura), procurou-se verificar estratégias de leitura, ou seja, se, ao ler os textos para trabalhos acadêmicos, o aluno: faz resumos, toma nota de trechos, assinala no próprio texto passagens importantes, seleciona e toma nota de conceitos, confia na sua memória ou tem outro(s) critério(s).

No Bloco III, ao qual foi dado o título Internet, indagou-se acerca da frequência com que ela é utilizada; se o aluno a vê como uma ferramenta de leitura assim como os livros e por quê.

No Bloco IV, Fontes diversificadas de leituras, as questões focalizaram o que se privilegia ao ler/ver: palavras impressas, imagens, palavras e imagens juntas, palavras digitalizadas (textos escritos na Internet), música, televisão, Internet em geral. 
No Bloco V, intitulado Leitura hoje e há vinte anos, foi questionado se o estudante concorda com a expressão: "os alunos de hoje em dia não leem" e por quê; se os pais deles estudaram/estudam e a que grau de ensino eles chegaram. No que diz respeito à relação com os pais, qual a posição do aluno quanto à leitura: se ele lê mais que seus pais, se eles leem mais que os filhos, se incentivavam/ incentivam a ler, se eles nunca incentivam a ler, se comentam acerca das leituras que fazem.

Por fim, no Bloco VI, Implicação dos métodos nos processos de alfabetização, solicitou-se que fosse comentada a frase de Paulo Freire (1985, p. 11-12): "A leitura de mundo antecede a leitura da palavra". ${ }^{8}$

$\mathrm{Na}$ análise geral dos dados, estiveram presentes reflexões com foco em alternativas de superação das dificuldades de leitura, encontradas nos cursos de formação de professores.

\section{A leitura dos dados: vislumbres}

As opiniões de professores, equipes pedagógico-administrativas, pais ou familiares de alunos e, destes últimos, coletadas na primeira fase da pesquisa (respostas ao questionário I) foram juntadas, sem distinção, em quatro grupos, apresentados a seguir: o primeiro diz respeito a modos de ler e à formação do leitor; o segundo, ao vínculo da leitura com a escrita; o terceiro refere-se à Internet como algo que atrapalha a leitura e a escrita; e o quarto destaca a importância da família na formação do leitor.

Essas respostas foram tomadas no conjunto constituído, sem distinção dos cursos, visto considerar-se que a soma de percepções de todos os sujeitos, no total 131 participantes, perpassa os fazeres pedagógicos e a aprendizagem e os dados coletados não apresentam grandes diferenças entre eles. Portanto, o foco da análise aqui apresentada não incidiu sobre os grupos individualmente, e sim sobre o que foi expresso de modo geral, sem desconsiderar-se, por princípio, o papel social dos quatro grupos participantes.

Grupo 1 - Modos de ler e a formação do leitorOs alunos não têm o hábito de ler;

- Os alunos ressentem-se da falta de método para ler;

- Os alunos têm pouca base escolar para a leitura;

- Os alunos leem para as provas e matérias que consideram essenciais;

\footnotetext{
${ }^{8}$ Cabe dizer que algumas das questões elaboradas nesta pesquisa estão em interface com as que foram apresentadas na pesquisa Retratos da Leitura no Brasil, sob a coordenação do Instituto Pró-Livro - IPL, divulgada em 2012, com o objetivo de "conhecer o comportamento leitor da população, especialmente com relação aos livros" e "medir a intensidade, forma, motivação e condições de leitura da população brasileira", segundo opinião dos entrevistados.
} 
- Quem lê tem o vocabulário ampliado;

- Os variados tipos de leituras se articulam.

Grupo 2 - Vínculo da leitura com a escrita

- A cultura acadêmica dissocia a leitura da escrita;

- Quem lê/escreve bem / Quem lê pouco não escreve bem / A prática leva à boa escrita.

Grupo 3 - Internet como algo que atrapalha a leitura e a escrita

- A Internet atrapalha na formação de bons leitores;

- A Internet atrapalha a leitura e escrita.

Grupo 4 - Importância da família na formação do leitor

- Pais e professores não incentivam os filhos e os alunos para a leitura: um ambiente alfabetizador com destaque do valor social da leitura por parte da família e dos professores estimula para a escrita.

Essas percepções mencionadas apontam para a necessidade de ações que possam abrir espaços efetivos de auxílio na formação de pais leitores. Órgãos governamentais e não governamentais, a mídia, escolas e universidades podem auxiliar tanto no que diz respeito à percepção dos pais e à necessidade de lerem e estarem atentos à leitura dos filhos quanto na abertura de amplas possibilidades para que eles exerçam, continuamente, a leitura.

Outro destaque assinalado refere-se àquilo que deve ser a razão primeira das escolas, ou seja, as ações voltadas à prática de leitura para além da decodificação, leituras essas que carecem ser mais efetivas e incluir, por exemplo, a Internet. $\mathrm{Na}$ formação do leitor, deve-se ter presente esse veículo de comunicação, visto que ele faz parte da nossa história no século XXI.

Um terceiro destaque, evidenciado na organização dos dados coletados na primeira fase da pesquisa, diz respeito à formação de leitores e como a leitura deve ser tratada, visto ser matéria-prima nos processos de ensino e de aprendizagem.

Por último, no entanto, não se colocando a questão de maneira a ordenála, visto que essas ações são complementares, há que se ter aulas de ensinar a ler ao longo da escolaridade, da vida acadêmica, para além dos cuidados com a leitura em todas as disciplinas. Que elas, além de ensinar sobre leitura somente, sejam lugares/momentos em que os seres humanos envolvidos a exercitem conjuntamente e de maneira prazerosa (REZENDE, 2009).

\section{Segunda fase da pesquisa}

Os dados obtidos na segunda fase, como já afirmado, foram pautados exclusivamente nas respostas dos alunos ao questionário apresentado. 
No Bloco I, denominado Leitura, quando foi perguntado, de início, Com que frequência você lêe, foi pedido aos discentes que optassem pelas alternativas que vão de 1 vezpor semana a 6 vezes por semana, todos os dias ou outra frequência, com espaço deixado em aberto para respostas.

Quadro 2 - Frequência de leitura

\begin{tabular}{|c|c|c|}
\hline Cursos & $\%$ & Frequência \\
\hline \multirow{5}{*}{ Pedagogia } & $50 \%$ & Todos os dias \\
\hline & $22 \%$ & 3 vezes por semana \\
\hline & $14 \%$ & 4 vezes por semana \\
\hline & $7 \%$ & 5 vezes por semana \\
\hline & $7 \%$ & 6 vezes por semana \\
\hline \multirow{3}{*}{ Letras Espanhol } & $60 \%$ & Todos os dias \\
\hline & $20 \%$ & 4 vezes por semana \\
\hline & $20 \%$ & 6 vezes por semana \\
\hline \multirow{6}{*}{ Letras Inglês A } & $46 \%$ & Todos os dias \\
\hline & $18 \%$ & 4 vezes por semana \\
\hline & $9 \%$ & 1 vez por semana \\
\hline & $9 \%$ & 3 vezes por semana \\
\hline & $9 \%$ & 5 vezes por semana \\
\hline & $9 \%$ & 6 vezes por semana \\
\hline Letras Inglês B & $100 \%$ & 4 vezes por semana \\
\hline \multirow{4}{*}{ Ciências Sociais } & $81 \%$ & Todos os dias \\
\hline & $9 \%$ & 3 vezes por semana \\
\hline & $9 \%$ & 5 vezes por semana \\
\hline & $1 \%$ & Resposta em branco \\
\hline
\end{tabular}

Fonte: As autoras.

A julgar pelas respostas, a rotina de leitura pode ser considerada de regular a boa. No entanto, há que se ver, nas respostas aos demais questionamentos, outros dados que complementam essas respostas. É o caso, por exemplo, da pergunta seguinte: Quanto tempo, em média, você dedica à leitura, a cada vez que lê? com as alternativas de 5 a 10 minutos, 11 a 20 min, 21 a 30 min, 31 a 40 min, 41 a 60 min e mais de uma hora. As respostas apontam para apenas alguns minutos, com exceção dos estudantes do curso de Letras Inglês A, que dizem ler de 40 a 60 minutos, e dos de Ciências Sociais, que dizem ler mais de uma hora por dia.

Essas respostas podem ser relacionadas à ideia de que quem lê pouco ou lê mal resiste ao ato de ler. "Quanto menos alguém é capaz de ler, menos deseja ler e, se tiver que fazê-lo, provavelmente não irá cumprir satisfatoriamente a tarefa" (REZENDE, 2009, p. 8), realizando-a de maneira que ela venha a contribuir no sentido de que o sujeito compreenda o que foi lido, situe-se e possa 
estabelecer relações com outros textos a partir do que leu, e, consequentemente, tenha mais elementos para intervir no mundo mais plenamente. $\mathrm{Na}$ sociedade do século XXI, a leitura é um dos requisitos para o exercício da cidadania. Ela está presente em todos os lugares, nas ruas, nos cartazes, nas lojas (FERNANDES, 2007), o que leva ao pensamento, por analogia, de que se pode vê-la como no enigma da esfinge: decifra-me ou devoro-te?! Mais ainda: em se tratando da leitura, é preciso ir além da decifração.

A seguir, são apresentadas as respostas à questão de múltipla escolha: Dentre as opções abaixo, qual(is) você lê com maior frequência? As alternativas foram: Notícia local; Policial (crimes/violência); Economia; Agronegócios; Esportes; Artes; Programação Cultural; Educação; Ciência; Meio Ambiente; Outro tipo de leitura, qual?

Quadro 3 - Opções de leitura

\begin{tabular}{|c|c|c|}
\hline Cursos & $\%$ & Opções \\
\hline \multirow{4}{*}{ Pedagogia } & $45 \%$ & Educação \\
\hline & $19 \%$ & notícia local \\
\hline & $7 \% *$ & policial; esporte; ciência; meio ambiente. \\
\hline & $4 \% *$ & artes; programação cultural \\
\hline \multirow{4}{*}{ Letras Espanhol } & $31 \%$ & notícia local \\
\hline & $15 \% *$ & educação; ciência \\
\hline & $8 \% *(32 \%)$ & $\begin{array}{c}\text { esporte; programação cultural; artes; meio } \\
\text { ambiente. }\end{array}$ \\
\hline & $7 \%$ & Policial \\
\hline \multirow{7}{*}{ Letras Inglês A } & $30 \%$ & Educação \\
\hline & $16 \%$ & noticia local \\
\hline & $14 \%$ & meio ambiente \\
\hline & $11 \%$ & programação cultural \\
\hline & $8 \% *(16 \%)$ & artes; policial \\
\hline & $5 \% *(10 \%)$ & economia; esporte \\
\hline & $3 \%$ & Ciências \\
\hline Letras Inglês B & $100 \%$ & Educação \\
\hline \multirow{5}{*}{ Ciências Sociais } & $24 \%$ & educação \\
\hline & $14 \% *(56 \%)$ & $\begin{array}{c}\text { economia; ciência; notícia local; programação } \\
\text { cultural }\end{array}$ \\
\hline & $7 \%$ & Artes \\
\hline & $4 \%$ & Policial \\
\hline & $3 \% *(9 \%)$ & agronegócio; esporte; meio ambiente. \\
\hline
\end{tabular}

Fonte: As autoras.

Nota: $\left(^{*}\right)$ Cada item possui essa percentagem.

\footnotetext{
${ }^{9}$ Ou se domina a leitura ou a vida fica restrita frente aos múltiplos textos e às amplas possibilidades de apresentações que os revestem.
} 
Ao visualizar esses dados, é forçoso lembrar que à universidade cabe oferecer múltiplas oportunidades para que os estudantes possam ver, falar e escutar, expressar sentimentos, experiências, opções e ideias, como parte da ambiência de leitura ${ }^{10}$ a ser vivenciada. Portanto, é importante a realização de atividades culturais diversificadas como cineclube com discussões de filmes, clube de literatura, teatro etc. Isso significa que os alunos, ao cursarem licenciatura, não deveriam ler somente textos voltados à área específica de atuação, mas também outros, que expressem diferentes olhares, advindos de variados gêneros textuais e oferecidos em diferentes suportes, ampliando, assim, o conhecimento da temática tratada.

$\mathrm{Na}$ sequência, constam dados com base no questionamento: Você compra livros? Se compra, quais os tipos que escolhe? (Questão aberta).

Quadro 4 - Compra de livros

\begin{tabular}{|c|c|c|}
\hline \multirow{2}{*}{ Cursos } & \multicolumn{2}{|c|}{ Você compra livros? Quais? } \\
\hline \multirow{4}{*}{ Pedagogia } & \% & Livros \\
\cline { 2 - 3 } & $39 \%$ & Educação \\
\cline { 2 - 3 } & $13 \%$ & Acadêmicos \\
\cline { 2 - 3 } & $9 \% *(27 \%)$ & entretenimento; literatura; religião. \\
\hline \multirow{3}{*}{ Letras Espanhol } & $4 \% *(20 \%)$ & $\begin{array}{c}\text { educação infantil; educação especial; inglês; } \\
\text { empréstimo/xerox; não compra. }\end{array}$ \\
\cline { 2 - 3 } & $40 \%$ & Literatura \\
\cline { 2 - 3 } & $40 \%$ & literatura estrangeira \\
\hline \multirow{3}{*}{ Letras Inglês A } & $20 \%$ & Gramática \\
\cline { 2 - 3 } & $30 \% *(60 \%)$ & literatura; acadêmicos \\
\cline { 2 - 3 } & $15 \%$ & Dicionário \\
\hline \multirow{2}{*}{ Letras Inglês B } & $5 \% *(25 \%)$ & relacionamento; moda; educação; reflexão; baixa da \\
& $50 \%$ & internet \\
\cline { 2 - 3 } & $50 \%$ & reflexão, relacionamentos \\
\hline \multirow{3}{*}{ Ciências Sociais } & $30 \%$ & contos e crônicas \\
\cline { 2 - 3 } & $15 \%$ & Sociologia \\
\cline { 2 - 3 } & $10 \% *(30 \%)$ & Acadêmicos \\
\cline { 2 - 3 } & $5 \% *(25 \%)$ & que agradam; economia; religião; antropologia; \\
empréstimo.
\end{tabular}

Fonte: As autoras.

Nota: $(*)$ Cada item possui essa percentagem.

O Quadro imediatamente anterior (4) permite ver que discentes de cada curso compram livros relacionados às suas áreas de conhecimento. Parece que cada um "lê o essencial para o desempenho das suas atividades escolares/aca-

\footnotetext{
${ }^{10}$ Para ver mais sobre ambiência de leitura, sugere-se a leitura de: REZENDE, Lucinea Aparecida de. Formação de leitores: um caminho possível. In: KARWOSKI, Acir Mário; GAYDECZKA, Beatriz (Orgs.) Leitura: leitores e bibliotecas no interior do Brasil. União da Vitória: Kaygangue, 2007. p. 33-44. Da mesma autora: Leitura e formação de leitores: vivências teórico-práticas. Londrina: EDUEL, 2009.
} 
dêmicas" (REZENDE, 2009, p. 3). Nesse aspecto, tem-se a ideia de que os alunos só se aproximam de textos relacionados à sua área de conhecimento, não avançando em direção a outros textos e temáticas, ampliando, aprofundando em várias direções suas visões de mundo.

Outra pergunta feita foi: Já teve vontade de adquirir um livro e não o fez?? Por que não o fez? (questão aberta). As respostas podem ser assim sintetizadas:

Quadro 5 - Vontade de adquirir livro

\begin{tabular}{|c|c|c|}
\hline \multirow{2}{*}{ Cursos } & $\mathbf{0}$ & Motivo \\
\hline \multirow{3}{*}{ Pedagogia } & $70 \%$ & dificuldade financeira \\
\cline { 2 - 3 } & $12 \%$ & não estava disponível \\
\cline { 2 - 3 } & $6 \% *(18 \%)$ & $\begin{array}{c}\text { falta de tempo para ler; prazo curto para } \\
\text { devolução; não passei por isso }\end{array}$ \\
\hline \multirow{2}{*}{ Letras Espanhol } & $80 \%$ & dificuldade financeira \\
\cline { 2 - 3 } & $20 \%$ & não passei por isso \\
\hline \multirow{2}{*}{ Letras Inglês A } & $82 \%$ & dificuldade financeira \\
\cline { 2 - 3 } & $9 \% *(18 \%)$ & não passei por isso; em branco \\
\hline Letras Inglês B & $100 \%$ & dificuldade financeira \\
\hline Ciências Sociais & $100 \%$ & dificuldade financeira \\
\hline
\end{tabular}

Fonte: As autoras.

Nota: $\left(^{*}\right)$ Cada item possui essa percentagem

Observando o Quadro 5, pode-se perceber que a maioria dos alunos diz não adquirir livros por dificuldade financeira. Essa problemática parece estar relacionada ao que disse Fernandes (2007), quando mencionou que falar de leitura no Brasil contemporâneo implica falar dos percalços para a formação do leitor e para a democratização da leitura no país. A fala de Silva (1986, p. 11-12) vem ao encontro da afirmação de Fernandes (2007), quando este autor diz que

[...] o acesso à leitura e aos livros nunca conseguiu ser democratizado em nosso meio. A então propalada "crise da leitura" não é uma doença destas últimas décadas e nem deste século: ela vem sendo reproduzida desde o período colonial, juntamente com a reprodução do analfabetismo, com a falta de biblioteca e com a inexistência de políticas concretas para a popularização do livro.

Quando o assunto foi/é a finalização de compras de livros, o quadro a seguir (6) apresenta as respostas recolhidas entre as alternativas: Livrarias, Internet e Outro Meio. 
Quadro 6 - Compra de livros em livrarias ou pela Internet

\begin{tabular}{|c|c|c|}
\hline \multirow{2}{*}{ Cursos } & $\mathbf{\%}$ & Meio de compra \\
\hline \multirow{3}{*}{ Pedagogia } & $50 \%$ & livrarias \\
\cline { 2 - 3 } & $45 \%$ & internet \\
\cline { 2 - 3 } & $5 \%$ & feira de livros \\
\hline \multirow{3}{*}{ Letras Espanhol } & $67 \%$ & internet \\
\cline { 2 - 3 } & $33 \%$ & livrarias \\
\hline \multirow{3}{*}{ Letras Inglês A } & $50 \%$ & livrarias \\
\cline { 2 - 3 } & $43 \%$ & internet \\
\cline { 2 - 3 } & $7 \%$ & sebo \\
\hline \multirow{2}{*}{ Letras Inglês B } & $67 \%$ & livrarias \\
\cline { 2 - 3 } & $33 \%$ & internet \\
\hline \multirow{2}{*}{ Ciências Sociais } & $43 \%$ & internet \\
\cline { 2 - 3 } & $33 \%$ & livrarias \\
\cline { 2 - 3 } & $24 \%$ & sebo \\
\hline
\end{tabular}

Fonte: As autoras.

Ao observar o quadro anterior (6), é possível ver que a preferência, considerado o conjunto dos cursos, é pela compra de livros em livrarias, seguida pela Internet. Ao avaliar-se essa questão em relação à anterior, referente à dificuldade financeira para a compra de livros, cumpre destacar que as bibliotecas escolares e universitárias carecem de investimentos. Ainda há muito a ser feito com vistas a constituir-se, amplamente, um público leitor, o que revela, dentre outras coisas, resultados insatisfatórios em relação às políticas públicas (FERNANDES, 2007).

Mediante a proposta de conhecer melhor, segundo a ótica dos alunos, a contribuição da universidade para a formação do leitor, as respostas podem ser agrupadas como no quadro seguinte (7). As alternativas oferecidas foram: "nunca", "muito pouco", "pouco", "médio", "acima da média" e "suficiente". 
Quadro 7 - Contribuição da universidade na formação do leitor

\begin{tabular}{|c|c|c|}
\hline Cursos & $\mathbf{\%}$ & Nível \\
\hline \multirow{3}{*}{ Pedagogia } & $57 \%$ & suficiente \\
\cline { 2 - 3 } & $29 \%$ & acima da média \\
\cline { 2 - 3 } & $14 \%$ & médio \\
\hline \multirow{3}{*}{ Letras Espanhol } & $80 \%$ & médio \\
\cline { 2 - 3 } & $20 \%$ & suficiente \\
\hline \multirow{4}{*}{ Letras Inglês A } & $46 \%$ & médio \\
\cline { 2 - 3 } & $27 \%$ & acima da média \\
\cline { 2 - 3 } & $18 \%$ & suficiente \\
\cline { 2 - 3 } & $9 \%$ & muito pouco \\
\hline Letras Inglês B & $100 \%$ & pouco \\
\hline \multirow{3}{*}{ Ciências Sociais } & $55 \%$ & médio \\
\cline { 2 - 3 } & $27 \%$ & acima da média \\
\cline { 2 - 3 } & $18 \%$ & pouco \\
\hline
\end{tabular}

Fonte: As autoras.

O quadro anterior (7) permite ver que os alunos consideram a universidade como contribuinte parcial para formar um bom leitor. Essa questão foi completada com as respostas abertas, apontando, por vezes, para a precariedade da contribuição da universidade na formação do leitor. No entanto, assim como na Educação Básica, na universidade se faz necessário um trabalho educativo de formação humana ampla, que possibilite ao sujeito crescimento em suas mais diferentes necessidades/possibilidades, inclusive no aprendizado da leitura, visto que para formar leitores, o professor necessariamente precisa ser inserido no mundo da leitura em sua formação. Nesse sentido, evidenciamos o que foi escrito por Saviani (1992, p. 15):

[...] o homem não se faz homem naturalmente; ele não nasce sabendo ser homem, vale dizer, ele não nasce sabendo sentir, pensar, avaliar, agir. Para saber pensar e sentir; para saber querer, agir ou avaliar é preciso aprender, o que implica o trabalho educativo.

No mesmo sentido da ponderação de Saviani, é preciso lembrar que o professor não nasce leitor; aprende a ler com o trabalho educativo de seus mestres: pais, professores, pares, entre outros, bem como em seu fazer. Faz parte desse universo a aquisição de livros e a contribuição da universidade na formação do leitor, visto haver a necessidade de superação das dificuldades encontradas para se alcançar índices mais elevados em termos de leitura entre os participantes da pesquisa, assim como na população brasileira em geral. 
O exame Pisa ${ }^{11}$, de 2009, apresenta a pontuação média dos países em leitura e o lugar ocupado por eles no ranking mundial:

Tabela 1 - Classificação dos países na pontuação média em leitura pelo PISA

\begin{tabular}{c|c|c}
\hline Classificação & País & Pontuação média \\
\hline $1^{\circ}$ & Xangai (China) & 556 \\
\hline $2^{\circ}$ & Coreia do Sul & 539 \\
\hline $3^{\circ}$ & Finlândia & 536 \\
\hline $4^{\circ}$ & Hong Kong & 533 \\
\hline $5^{\circ}$ & Singapura & 526 \\
\hline $6^{\circ}$ & Canadá & 524 \\
\hline $7^{\circ}$ & Nova Zelândia & 521 \\
\hline $8^{\circ}$ & Japão & 520 \\
\hline $9^{\circ}$ & Austrália & 515 \\
\hline $10^{\circ}$ & Holanda & 508 \\
\hline $53^{\circ}$ & Brasil & 412 \\
\hline
\end{tabular}

Fonte: Okada (2010).

Ainda que o Brasil tenha tido um pequeno avanço neste teste (em 2006, sua posição foi $54^{\circ}$ ), tem-se claro que é possível crescer ainda mais, tendo em vista os demais países que alcançaram melhores colocações, evidenciando que a superação das frágeis práticas de leitura é possível e necessária.

$\mathrm{Na}$ sequência de questões, foi perguntado aos discentes se os espaços de leitura existentes são bem aproveitados pelos professores. As respostas permitem verificar que a maioria dos alunos afirma não haver incentivo à leitura por parte dos professores e a ocorrência de solicitações para a sua realização em casa. Somente os alunos de Letras Espanhol mencionaram que os professores incentivam a ler. Há indicadores de que os espaços de leitura são mais utilizados pelos alunos do que pelos professores, há cobranças de leituras e atividades por parte destes últimos, porém a maior exigência concentra-se em ler em sala de aula ou para pesquisas. Dessa maneira, os dados sinalizam ao professor a necessidade de maior contribuição, continuamente, com a formação do leitor, qualquer que seja a área de conhecimento à qual se dedica.

Finalizando o bloco I, foi solicitado: "Gostaríamos que você comentasse a frase de Flaubert Leia para viver". Os estudantes disseram que ler: é indispensável; traz conhecimento; nos torna mais críticos; permite-nos sermos transportados; ajuda a inteirarmo-nos de determinados assuntos; abre os olhos; é saudável; permite relaxar; abre novos caminhos; estimula a reflexão e criatividade; ajuda a compreender o significado da vida.

\footnotetext{
${ }^{11}$ Pisa=Programa Internacional de Avaliação de Alunos. A média dos países é 500 pontos: quanto mais distante da média, melhor ou pior é o resultado. Em 2009, a pesquisa foi feita com 470 mil estudantes de 65 países. A cada ano, é dada ênfase a uma disciplina: neste ano, foi a vez de leitura. (OKADA, 2010).
} 
No bloco II, no que diz respeito a ler textos na universidade, foram apresentadas as opções: "fazer resumos", "tomar nota de trechos", "assinalar no próprio texto passagens importantes", "selecionar e tomar nota de conceitos", "confiar na memória", "outros". Os dados podem ser visualizados no quadro adiante (8).

Quadro 8 - Estratégias de leitura

\begin{tabular}{|c|c|c|}
\hline \multirow{2}{*}{ Ao ler os textos para trabalhos acadêmicos, você: } \\
\hline Cursos & $\%$ & Opções \\
\hline \multirow{4}{*}{ Pedagogia } & $45 \%$ & assinala no próprio texto passagens importantes \\
\cline { 2 - 3 } & $20 \%$ & faz resumos \\
\cline { 2 - 3 } & $19 \%$ & toma nota de trechos \\
\hline \multirow{4}{*}{ Letras Espanhol } & $16 \%$ & seleciona e toma nota de conceitos \\
\cline { 2 - 3 } & $56 \%$ & assinala no próprio texto passagens importantes \\
\cline { 2 - 3 } & $22 \%$ & faz resumos \\
\hline \multirow{3}{*}{ Letras Inglês A } & $11 \% *(22 \%)$ & toma nota de trechos; seleciona e toma nota de \\
& $59 \%$ & conceitos \\
\cline { 2 - 3 } & $17 \%$ & assinala no próprio texto passagens importantes \\
\cline { 2 - 3 } & $12 \% *(24 \%)$ & faz resumos; seleciona e toma nota de conceitos \\
\hline Letras Inglês B & $100 \%$ & assinala no próprio texto passagens importantes \\
\hline \multirow{3}{*}{ Ciências Sociais } & $28 \%$ & assinala no próprio texto passagens importantes \\
\cline { 2 - 3 } & $26 \% *(52 \%)$ & toma nota de trechos; seleciona e toma nota de \\
\cline { 2 - 3 } & $14 \%$ & conceitos \\
\cline { 2 - 3 } & $3 \% *(6 \%)$ & caz resumos \\
\hline
\end{tabular}

Fonte: As autoras.

Nota: $\left(^{*}\right)$ Cada item possui essa percentagem.

No quadro anterior (8), pode-se visualizar que o maior índice apontado, no que diz respeito à maneira de ler textos acadêmicos, refere-se a assinalar no próprio texto as passagens mais importantes e o menor índice relaciona-se a confiar na memória (com exceção de Ciências Sociais, 0\% nos outros cursos), e são poucos os que registram com suas palavras as ideias do autor.

Assinalar no texto pontos importantes é uma estratégia de leitura que permite ao leitor, ao retornar a um texto lido anteriormente, recordar-se mais facilmente do assunto, já que nem sempre são guardadas todas as informações na memória. No entanto, outras estratégias de leitura ${ }^{12}$ podem ser exploradas e não foram citadas.

\footnotetext{
${ }^{12}$ Sobre estratégias de leitura, ver, dentre outros textos: SOLÉ, Isabel. Estratégias de leitura. Porto Alegre: ArtMed, 1998. Também: RANGEL, Mary. Dinâmicas de leitura para sala de aula. Petrópolis: Vozes, 1990 .
} 
No Bloco III de questões, ao qual foi dado o título Internet, indagou-se acerca da frequência com que ela é utilizada, com alternativas que vão de 1 vez. por semana a 6 vezes por semana, todos os dias ou nunca. As respostas dos discentes indicam que utilizam a Internet todos os dias: Pedagogia, 93\%; Letras Inglês A, 91\%; Letras Inglês B, 100\% ; Letras Espanhol, 100\%; e Ciências Sociais, 91\%.

Vê-se, portanto, que a Internet está incorporada à leitura dos alunos. Ela é um meio de comunicação que se expandiu pelos diferentes cantos da terra. As tecnologias de informação e comunicação na Internet disponibilizam o acervo de bibliotecas digitais e virtuais, expandindo os limites do ensino e da pesquisa. Ela é uma ferramenta que abre caminhos entre o que acontece no mundo e na escola, propiciando inovar na leitura e na construção do conhecimento.

A propósito, frente ao questionamento: Você pensa que a Internet pode ser considerada uma ferramenta de leitura, assim como os livros? Por quê?, todos os alunos afirmaram ser a Internet uma ferramenta de leitura assim como o livro. O uso da Internet é diário e parece que é visto como de mais fácil acesso do que o livro. Essa constatação leva a pensar que na leitura internética existem a dinamicidade, as inter-relações imprimindo algo novo ao ato de ler, e isso precisa ser considerado nos processos de ensinar e de aprender.

Quem faz uso contínuo do computador e da Internet, por certo já experimentou a sensação nova e provocante de que o tempo e o espaço, nessa dimensão de conhecer, permitem novas compreensões. O estar distante e o estar perto já não podem ser entendidos como o eram, simplesmente. A maneira de relacionar-se em rede permite aproximações múltiplas e variadas e eu acrescentaria: nem por isso, necessariamente menos profundas. (REZENDE, 2010, p. 81).

Compreende-se, conforme a citação anterior, que os alunos estão em contato diário com a Internet e com textos virtuais. A propósito, no século em que vivemos, tratar de ensino e aprendizagem implica acessar a chamada Tecnologia da Informação e Comunicação (TIC), tida como um conjunto de recursos tecnológicos presentes nos diversos segmentos da sociedade, inclusive na educação, que se utiliza das funções de hardware, software e telecomunicações. Nessa direção, "a leitura é um vício para muitas pessoas, os computadores são um vício para muitas pessoas, e a combinação da leitura com os computadores pode tornar-se irresistível" (SMITH, 1999, p. 155). Portanto, ensinar e aprender hoje exigem horizontes mais amplos, e certamente os avanços tecnológicos podem somar nesse processo, pois fazem parte da vivência do educando e dos professores.

No bloco IV, intitulado Fontes diversificadas de leituras, as questões focalizaram o que se privilegia ao ler/ver: palavras impressas, imagens, palavras e imagens juntas, palavras digitalizadas (textos escritos na Internet), música, televisão, Internet em geral. 
Quadro 9 - Fontes privilegiadas de leitura

\begin{tabular}{|c|c|c|}
\hline \multicolumn{3}{|c|}{ O que você privilegia para ler/ver? } \\
\hline Cursos & $\%$ & Fontes \\
\hline \multirow{5}{*}{ Pedagogia } & $23 \%$ & palavras impressas \\
\hline & $20 \%$ & internet \\
\hline & $17 \%$ & palavras e imagens juntas \\
\hline & $14 \%$ & televisão \\
\hline & $9 \% *(27)$ & imagens; palavras digitalizadas; música \\
\hline \multirow{4}{*}{ Letras Espanhol } & $30 \%$ & palavras impressas \\
\hline & $30 \%$ & música \\
\hline & $20 \%$ & Internet \\
\hline & $10 \% *(20)$ & televisão; imagem \\
\hline \multirow{5}{*}{ Letras Inglês A } & $25 \%$ & Internet \\
\hline & $22 \%$ & palavras e imagens juntas \\
\hline & $18 \%$ & música \\
\hline & $14 \%$ & palavras digitalizadas \\
\hline & $7 \% *(21)$ & palavras impressas; imagem; televisão \\
\hline \multirow{2}{*}{ Letras Inglês B } & $50 \%$ & palavras impressas \\
\hline & $50 \%$ & palavras e imagens juntas \\
\hline \multirow{4}{*}{ Ciências Sociais } & $23 \%$ & palavras impressas \\
\hline & $18 \%$ & Internet \\
\hline & $13 \% *(52)$ & $\begin{array}{c}\text { palavras e imagens juntas; palavras digitalizadas; musica; } \\
\text { televisão }\end{array}$ \\
\hline & $7 \%$ & Imagem \\
\hline
\end{tabular}

Fonte: As autoras.

Nota: $\left(^{*}\right)$ Cada item possui essa percentagem.

A leitura do quadro anterior (9) leva a pensar que um texto pode se manifestar visualmente, como uma pintura, por meio da linguagem verbal, visual e musical, como o cinema, as histórias em quadrinhos. "A TV, o cinema, o teatro, outdoors, placas e letreiros em geral são exemplos dessa presença contínua da imagem em nossas vidas. No entanto, ainda que o contexto seja esse, a escola/ universidade tem descuidado da leitura da imagem" (REZENDE, 2009, p. 3).

Verifica-se constantemente a presença de textos e imagens em conjunto, circulando em meio a toda a sociedade. Trata-se de uma união que permite a expressão do significado do texto de forma mais abrangente. No entanto, ainda que se tenha, neste século, a convivência das múltiplas leituras, parece haver uma supervalorização da palavra impressa, desconsiderando-se, na prática, as inter-relações textuais ${ }^{13}$. Nesse sentido, há que se ampliar a visão de leitura, tendo-se mais presente o texto em suas múltiplas possibilidades de apresentação.

\footnotetext{
${ }^{13}$ A propósito, ver, por exemplo, a obra de NEVES et al. (Org.). Ler e escrever: compromisso de todas as áreas. Porto Alegre: UFRGS, 1998.
} 
"A leitura se realiza a partir do diálogo do leitor com o objeto lido - seja escrito, sonoro, seja um gesto, uma imagem, um acontecimento [...]" (MARTINS, 2006, p. 33), o que leva a ponderar que a multiplicidade de leitura está ao alcance de professores e alunos.

De acordo com as justificativas apresentadas, pode-se perceber o interesse por textos veiculados na Internet, sem a desconsideração da leitura em outros suportes. Destaca-se a resposta de um aluno de Letras Espanhol, que privilegia a leitura de um bom livro. Esses dados podem ser relacionados aos escritos de Chartier (2002, p. 23):

É agora um único aparelho, o computador, que faz surgir diante do leitor os diversos tipos de textos tradicionalmente distribuídos entre objetos diferentes. Todos os textos, sejam eles de qualquer gênero, são lidos em um mesmo suporte (a tela do computador) e nas mesmas formas (geralmente as que são decididas pelo leitor). Cria-se assim uma continuidade que não mais diferencia os diversos discursos a partir de sua própria materialidade. Urge disso uma primeira inquietação ou confusão dos leitores, que devem enfrentar o desaparecimento dos critérios imediatos, visíveis, materiais, que lhes permitiam distinguir, classificar e hierarquizar os discursos.

Verifica-se uma nova forma de leitura, não raro descontínua, em que se busca o fragmento textual do qual o leitor quer se apoderar, sem que sejam, necessariamente, buscadas/percebidas a identidade e a coerência da totalidade textual. Segundo Chartier (2002), esse mundo eletrônico propõe uma nova forma de difusão da escrita. Trata-se de uma revolução na modalidade técnica da produção do escrito.

No Bloco V, denominado Leitura hoje e há vinte anos, foi proposta a questão: Você concorda com a expressão "os alunos de hoje em dia não leem”?, com opções Sim, Não e Por quê? 


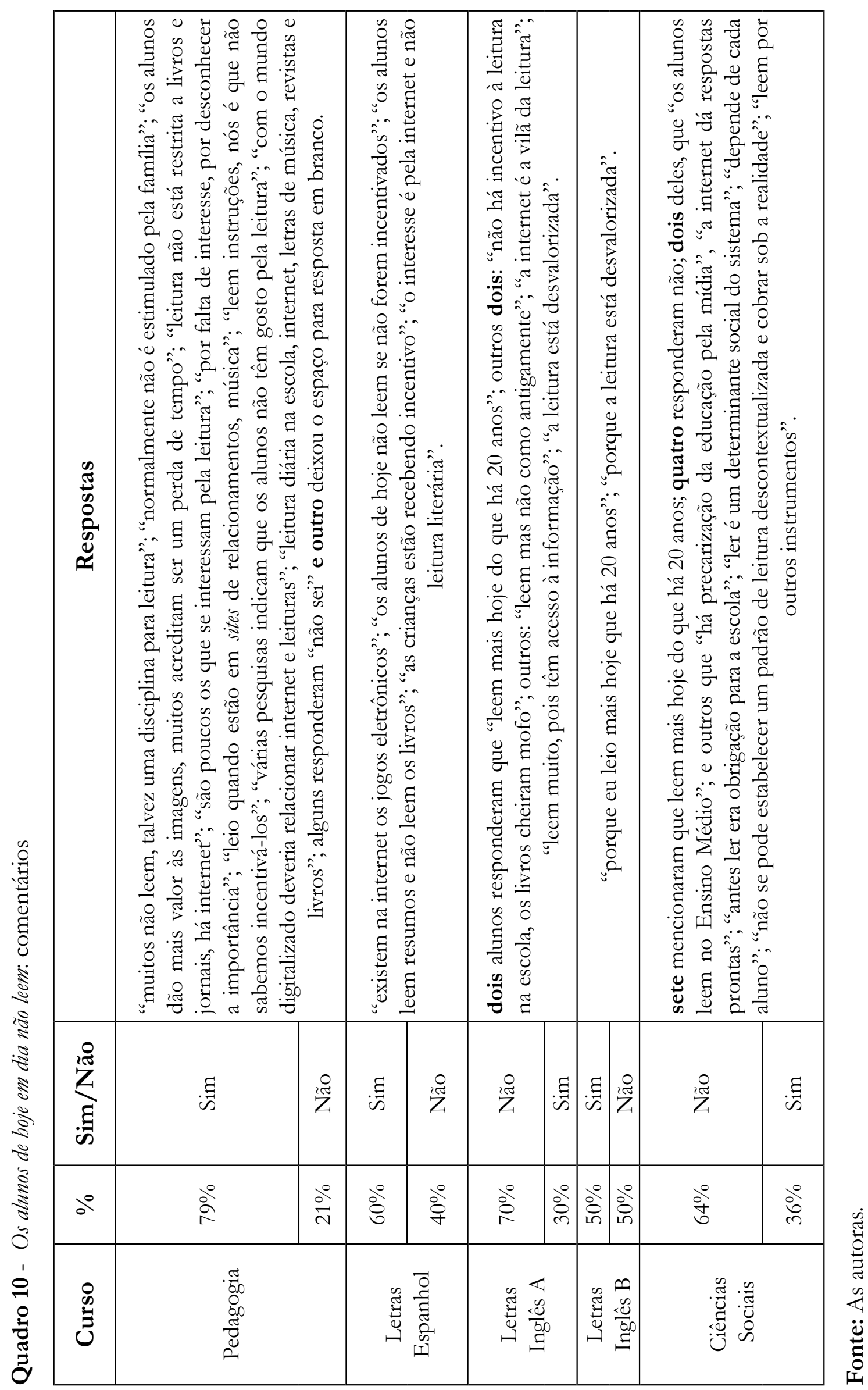

Práxis Educativa, Ponta Grossa, v. 8, n. 1, p. 243-272, jan./jun. 2013 
O quadro 10 apresenta comentários acerca da frase Os alunos de hoje em dia não leem. Eles evidenciam diferentes olhares acerca da leitura. As ideias apresentadas vão desde a percepção de que se lê mais hoje que há 20 anos até o extremo oposto, neste último caso, em maior índice, apontando para a falta de interesse pela leitura. A Internet permeia os comentários, aparecendo ora como auxiliar, ora como vilã, pelo fácil acesso que ela permite às informações, bem como pelo mau uso que é possível fazer dela, como vemos na indicação de que os alunos leem resumos e não leem os livros ou dá respostas prontas. Há, por outro lado, o reconhecimento, por parte de alguns, de que a leitura é feita de formas diferentes, ou seja, existem outros meios de acesso à leitura, não limitados aos livros.

Segundo Chartier (2002, p. 23), com o advento da Internet, houve uma alteração:

Surge disso uma primeira inquietação ou confusão dos leitores, que devem enfrentar o desaparecimento dos critérios imediatos, visíveis, materiais, que lhes permitiam distinguir, classificar e hierarquizar os discursos.

O que torna mais difícil, contudo, é a percepção da obra como obra. A leitura na tela é geralmente descontínua e busca, a partir de palavras-chave ou rubricas temáticas, o fragmento textual do qual quer se apoderar (um artigo em um periódico, um capítulo em um livro, uma informação em um web site) sem que necessariamente sejam percebidas a identidade e a coerência da totalidade textual que contém esse elemento.

Verifica-se, com o autor, que "quanto à ordem dos discursos, o mundo eletrônico provoca uma tríplice ruptura: propõe uma nova técnica de difusão da escrita, incita uma nova relação com os textos, impõe-lhes uma nova forma de inscrição." (CHARTIER, 2002, p. 23-24). Nessa modalidade de leitura (virtual), o leitor pode validar qualquer demonstração, consultando os textos já digitalizados. Outro dado importante é que o texto eletrônico é um texto móvel, maleável e aberto.

O leitor pode intervir em seu próprio conteúdo e não somente nos espaços deixados em branco, pela composição tipográfica. Pode deslocar, recortar, estender, recompor as unidades textuais das quais se apodera. (CHARTIER, 2002, p. 25).

Ainda neste bloco, foi perguntado se os pais dos discentes estudaram ou estudam. As opções contemplaram diferentes níveis de escolaridade. 
Quadro 11 - Escolaridade dos pais

\begin{tabular}{|c|c|c|}
\hline Cursos & $\%$ & Escolaridade \\
\hline \multirow{4}{*}{ Pedagogia } & $47 \%$ & Ensino Fundamental $-4^{a}$. série \\
\hline & $17 \%$ & Especialização \\
\hline & $12 \% *(24 \%)$ & $\begin{array}{l}\text { Ensino Fundamental completo; Ensino Superior } \\
\text { completo }\end{array}$ \\
\hline & $6 \% *(12 \%)$ & Ensino Médio incompleto; Ensino Médio completo; \\
\hline \multirow{2}{*}{ Letras Espanhol } & $33 \% *(66 \%)$ & $\begin{array}{l}\text { Ensino Fundamental }-4^{\text {a }} \text {. série; Ensino Médio } \\
\text { completo }\end{array}$ \\
\hline & $17 \% *(34 \%)$ & $\begin{array}{l}\text { Ensino Fundamental completo; Ensino Superior } \\
\text { completo }\end{array}$ \\
\hline \multirow{4}{*}{ Letras Inglês A } & $38 \%$ & Ensino Fundamental $-4^{\mathrm{a}}$. série \\
\hline & $31 \%$ & Ensino Médio completo \\
\hline & $15 \%$ & Ensino Superior incompleto \\
\hline & $8 \% *(16 \%)$ & Ensino Superior completo; Especialização \\
\hline Letras Inglês B & $100 \%$ & Ensino Fundamental $-4^{\text {a }}$. série \\
\hline \multirow[b]{2}{*}{ Ciências Sociais } & $67 \%$ & Ensino Médio completo \\
\hline & $11 \% *(33 \%)$ & $\begin{array}{c}\text { Ensino Fundamental completo; Ensino Superior } \\
\text { incompleto; Mestrado }\end{array}$ \\
\hline
\end{tabular}

Fonte: As autoras.

Nota: $\left(^{*}\right)$ Cada item possui essa percentagem.

O quadro anterior (11) permite perceber que os pais dos alunos cursaram, no mínimo, o Ensino Fundamental até a $4^{\mathrm{a}}$ série, variando de 8 a 17\% o número, por curso, dos que chegaram ao Ensino Superior. À exceção do curso Letras Inglês $\mathrm{B}$, há menções à escolaridade em níveis subsequentes ao superior. Isso permite pensar na possibilidade de atribuição de valor positivo ao estudo e em um relacionamento com os filhos que contemple essa visão.

$\mathrm{Na}$ questão Em relação aos seus pais, qual a sua posição quanto à leitura?, foram apresentadas as alternativas: você lê mais que eles, eles leem mais que você, eles incentivam você a ler, eles nunca o(a) incentivam a ler e eles comentam com você acerca de leituras que fazem, e as respostas abaixo: 
Quadro 12 - Leitura dos alunos em relação aos pais

\begin{tabular}{|c|c|c|}
\hline Cursos & $\%$ & Posição \\
\hline \multirow{4}{*}{ Pedagogia } & $45 \%$ & você lê mais que eles \\
\hline & $23 \%$ & eles incentivam você a ler \\
\hline & $14 \% *(28 \%)$ & $\begin{array}{l}\text { eles leem mais que você; eles comentam com você } \\
\text { acerca de leituras que fazem }\end{array}$ \\
\hline & $4 \%$ & eles nunca o(a) incentivam a ler \\
\hline \multirow[b]{2}{*}{ Letras Espanhol } & $67 \%$ & você lê mais que eles \\
\hline & $16 \% *(32 \%)$ & $\begin{array}{c}\text { eles incentivam você a ler; eles nunca o(a) incentivam } \\
\text { a ler }\end{array}$ \\
\hline \multirow{3}{*}{ Letras Inglês A } & $55 \%$ & você lê mais que eles \\
\hline & $18 \% *(36 \%)$ & $\begin{array}{l}\text { eles incentivam você a ler; eles comentam com você } \\
\text { acerca de leituras que fazem }\end{array}$ \\
\hline & $9 \%$ & eles leem mais que você \\
\hline \multirow{2}{*}{ Letras Inglês B } & $50 \%$ & você lê mais que eles \\
\hline & $50 \%$ & eles comentam com você acerca de leituras que fazem \\
\hline \multirow{4}{*}{ Ciências Sociais } & $50 \%$ & você lê mais que eles \\
\hline & $25 \%$ & eles comentam com você acerca de leituras que fazem \\
\hline & $17 \%$ & eles incentivam você a ler \\
\hline & $8 \%$ & eles leem mais que você \\
\hline
\end{tabular}

Fonte: As autoras.

Nota: $\left({ }^{*}\right)$ Cada item possui essa percentagem.

Conforme o quadro elaborado (12), pode-se notar que os discentes leem mais que os pais, ainda que esses números não sejam expressivos. No caso de Letras Inglês B, há um empate nesse item. Esses dados permitem estabelecer conexão com o que foi dito por Rezende (2010, p. 82):

Socialmente, os mais jovens - crianças e adolescentes - são tidos como aqueles que ainda "têm muito que aprender". Entende-se que a leitura de mundo deles ainda é restrita, frente à "dos mais velhos". Em nossos dias, isso tem novos contornos: os "mais velhos" necessitam continuar aprendendo para compreender melhor o mundo em que vivem e estar nele: os jovens, por sua vez, parecem ser aqueles que mais facilmente adentram ao mundo das conexões e redes.

A citação mencionada ajuda a pensar que a relação pais e filhos, no que diz respeito ao conhecimento, vai se alterando com o tempo, com a possibilidade de os filhos estudarem mais, lerem mais que os pais, talvez pela ajuda aos jovens com a proximidade da tecnologia. Por outro lado, vê-se que a leitura dos graduandos ainda está longe do desejável, pois, se eles estão no período de formação superior, é de supor-se que esse seja um tempo de maximização de leituras, o que não parece ocorrer. 
A última solicitação feita no Bloco VI de questões foi: Gostariamos que você comentasse a frase de Paulo Freire: "A leitura de mundo antecede a leitura da palavra." As respostas indicam que todos os alunos consideram que compreender o que acontece à volta é uma forma de leitura e essa leitura antecede a leitura das palavras. Nesse aspecto, cumpre lembrar as palavras de Freire (1985), quando escreveu que a leitura de mundo não se dissocia da leitura da palavra, pois ler é um ato político. Nesse sentido, a leitura não é uma decodificação, mas, sim, um elemento que liga o ser ao seu mundo histórico e social, levando-o a práticas conscientes, transformando e alterando suas atitudes com vistas à mudança social.

\section{Considerações finais}

As ideias circulantes acerca da leitura, identificadas neste estudo, podem ser assim resumidas: os alunos não se dedicam à leitura continuamente e com profundidade, leem para as provas e matérias que consideram essenciais; quem lê tem o vocabulário ampliado; a cultura acadêmica dissocia a leitura da escrita; quem lê escreve bem; os variados tipos de leitura se articulam; a Internet atrapalha na formação de bons leitores; pais e professores não incentivam à leitura.

Somadas a essas ideias, o estudo feito permite considerar que, em relação às práticas de leitura na universidade:

- o tempo, em média, dedicado à leitura, é pouco, com sensível melhora se olharmos para as respostas dos estudantes de Letras Inglês A e dos de Ciências Sociais;

- $\quad$ as preferências de leitura são, pela ordem: palavras impressas; palavras e imagens juntas; internet; música; televisão; imagens e palavras digitalizadas. Parece haver uma supervalorização da palavra impressa no tocante a fontes privilegiadas de leitura, na universidade, apesar das outras indicações;

- $\quad$ os gêneros textuais lidos com maior frequência (variação de 14 a 100\%; neste último caso, assinalada a educação, por estudantes de Letras Inglês B) são, por ordem: Educação, Notícia Local, Economia, Ciência e Programação Cultural;

- os livros comprados são, predominantemente, voltados à educação, seguidos daqueles voltados à reflexão, relacionamentos, contos e crônicas, literatura nacional e estrangeira;

- $\quad$ há manifesta dificuldade financeira para a aquisição de livros;

- a compra de livros é feita predominantemente em livrarias e só raramente isso é feito pela Internet; 
- $\quad$ a universidade é vista como contribuinte parcial na formação do leitor;

- poucos espaços são considerados de incentivo à leitura, e foi dito que eles não são amplamente explorados pelos professores;

- frente à tarefa dos alunos de comentar a frase de Flaubert: "Leia para viver", eles relacionaram leitura a: indispensável; conhecimento; crítica; transporte; aproximação com determinados assuntos; abrir os olhos; hábito saudável; relaxamento; novos caminhos; reflexão e criatividade; compreender o significado da vida;

- $\quad$ as estratégias de leitura de textos apontadas pelos estudantes são limitadas a assinalar no próprio texto passagens importantes, havendo raras menções à elaboração de resumo, tomar nota e selecionar dados;

- $\quad$ todos os alunos afirmam ser a Internet uma ferramenta de leitura como o livro;

- $\quad$ ao comentar a frase: “Os alunos de hoje em dia não leem”, os discentes evidenciam diferentes olhares acerca da leitura. Há o reconhecimento de que a leitura pode ser feita em variados suportes. A Internet ora é vista como auxiliar, ora como vilã, pelo fácil acesso que ela permite às informações, bem como pelo mau uso que é possível fazer dela;

- o Ensino Fundamental pode ser considerado como a escolaridade mínima dos pais, variando de 8 a 17\% o número, por curso, dos que chegaram ao Ensino Superior;

- a respeito da leitura dos alunos em relação a seus pais, podemos notar que os discentes leem um pouco mais que os pais, porém esses números não são expressivos;

- $\quad$ os comentários dos alunos acerca da frase de Paulo Freire: "A leitura de mundo antecede a leitura da palavra" indicam haver, por parte deles, inferência, intuição, talvez, acerca de a leitura pressupor uma perspectiva crítica de mundo e ir além da decifração de palavras.

O estudo feito permite perceber, de acordo com os participantes, que os alunos não leem suficientemente. Esses dados são corroborados por outras pesquisas e testes na área da educação, como a já mencionada pesquisa Retratos da Leitura no Brasil (2012), que apontou a média de 4 livros lidos ao ano pelos brasileiros. Lembramos que a leitura não é compreendida como restrita ao consumo de livros, mas eles são considerados como um tradicional suporte para a leitura e, desse modo, a referência anterior provoca preocupação, visto que a relação da população em geral com o livro não tem sido muito estreita, como apontam dados da pesquisa Retratos da Leitura no Brasil (2012) e o estudo ora apresentado. 
Por outro lado, observações junto ao universo acadêmico permitem ver a leitura sendo tratada como se fosse do domínio de todos, ainda que haja manifestações no dia a dia, por parte de professores, equipes de apoio pedagógico e pais, além dos próprios alunos, apontando para o fato de os estudantes lerem pouco. Tem-se, portanto, uma situação que está a requerer atuação mais específica, voltada à leitura na universidade, por parte daqueles que a constituem, pois ela é vista pelos estudantes como contribuinte parcial na formação do leitor.

Os projetos de pesquisa são tidos como espaços em que a leitura é incentivada e há várias indicações de que professores motivam seus alunos a ler. Por outro lado, esses espaços são tidos como poucos e também, na visão dos estudantes, pouco explorados pelos professores, havendo predominância do texto impresso nas atividades em sala de aula. Sobre a biblioteca, um aluno chega a dizer que os livros cheiram mofo.

Os estudantes apresentam estratégias limitadas de leitura. As que foram apontadas por eles correspondem a assinalar no próprio texto passagens importantes, havendo algumas poucas menções à elaboração de resumo, tomar nota e selecionar dados considerados relevantes. No entanto, eles, ao comentarem frases apresentadas na pesquisa, estabelecem relação da leitura de mundo com a leitura da palavra, indicando que fazem inferência acerca de a leitura pressupor uma perspectiva crítica de mundo e ir além da decifração de palavras.

A Internet, sem nos esquecermos dos aspectos político-sociais que envolvem o acesso a ela, enquanto aparato tecnológico está, de alguma forma, à disposição de professores e alunos com possível acesso a ela, correspondendo a uma ferramenta que faz o que se deseja que faça (quase sempre). À medida que ela é usada, tem-se a possibilidade de teclar, desfazer, deletar, ir adiante ou voltar no texto, localizar informações pontuais, estabelecer relação com outros textos, copiar, recortar, colar, alterar campos, formas; o texto torna-se nosso, algo que passa a fazer parte da nossa funcionalidade e modo de pensar. Fazer do seu uso rotina implica novas formas de relação do sujeito com o texto, com a informação, com o conhecimento, portanto. Tais maneiras de uso não aparecem explicitamente nos dados que nos foram fornecidos.

Se essa opção representa um avanço, por outro lado, faz-se necessário lembrar: quem opera a máquina é o ser humano. E vamos a ela, à máquina, com tudo o que somos, pensamos, sentimos. As possibilidades podem ser exploradas dentre tantas, não cabendo aqui discutir a respeito do conhecimento fácil, do mau uso, do desrespeito à ideia do outro, o que pode levar a apropriações indevidas, como foi apontado pelos estudantes neste estudo. Superar o desafio posto e outros passa pelo uso contínuo dessa ferramenta a ser explorada e mediada pelo professor. 
Nas manifestações dos estudantes, está indicada a dificuldade financeira para a compra de livros; parte dessa dificuldade poderia ser ao menos minimizada com a compra pela Internet e ou em grupo, mas essa hipótese não está considerada, amplamente, por eles. Outros estudos podem mostrar se o professor se utiliza dessa modalidade de compra de livros, bem como o uso que está sendo feito da Internet nos processos de ensino e aprendizagem.

Tratar dessa temática passa, também, pela compreensão de educação como algo complexo, que contempla a relação com o outro e tudo o que a permeia. Restringir-se ao uso de aparatos tecnológicos como se fossem um visualizador de textos, que também permitem a sua produção, como máquina de escrever, significa olhar e querer utilizá-los como quem tem em mãos um avião de última geração e só sabe pilotar o 14-Bis, de Santos Dumont, com todo o respeito à criação de Dumont.

Outro aspecto evidenciado neste estudo diz respeito à família. Os dados coletados indicam uma pequena influência exercida sobre os alunos no tocante à leitura. O incentivo da família em relação à leitura, fazendo parte desse universo a leitura exercida por ela, bem como a leitura e contação de história aos filhos, desde a infância, o uso da biblioteca escolar e, posteriormente, universitária, têm importância a ser destacada na formação de leitores comprometidos com o ato de ler. No entanto, essa ambiência inicial de leitura é pouco relatada pelos estudantes. Estes últimos leem mais, ainda que em número pouco expressivo, do que os pais o fazem. Talvez pudéssemos alegar que a escolaridade dos pais seja a causa da não contundente influência deles no que diz respeito à leitura dos filhos; no entanto, isso não seria oportuno dizer, visto que estamos tratando de acadêmicos que, não raro, não se sentem e não são vistos como leitores, como aqueles que leem contínua e amplamente, com profundidade, dedicando significativa parcela do tempo a essa atividade.

Questões culturais se fazem presentes quando é feita referência à leitura e formação de leitores. Alguns tópicos a elencar: o valor atribuído ao conhecimento sólido em nossa sociedade; a ideia do imediatismo - tudo pode e deve ser conseguido rapidamente, do jeito mais fácil - ; o reconhecimento do valor da leitura, mas não a sua assunção plena, como indica o tempo, em média, dedicado a ela por boa parte dos alunos.

Mediante as ideias apresentadas, percebe-se que obstáculos vislumbrados passam por aspectos socioculturais e políticos, que compreendem políticas públicas e modos de ser e pensar, até o fazer de pais no incentivo à leitura. Passa também pelas práticas de professores e alunos, que podem, dentre outras coisas, tratar da leitura e com a leitura atribuindo-lhe a importância com que ela aparece, neste início de século, em nossas vidas, explorando-se desde a sua relação com a 
nossa visão de mundo até estratégias que possam auxiliar no ato de ler. Ela nos afeta muito intensamente para ficar restrita ao âmbito do pressuposto de que é dominada pelos alunos e que se restringe à palavra escrita, sem negligenciarmos a importância da escrita na vida em sociedade.

Ressalta-se a necessidade de, na universidade, atentar-se às múltiplas leituras e às diversificadas relações que elas comportam entre si. Mais ainda: há que se tratar da leitura e de leitores não só a partir do pressuposto que os alunos universitários são leitores, mas a partir de dados que indicam, não raro, a possibilidade de o desempenho do estudante poder ser melhorado em relação à leitura, como visto em países melhor colocados nos índices macro (países) de leitura, como é o caso do exame Pisa (2009) ${ }^{14}$, já mencionado neste estudo.

\section{Referências}

BAKHTIN, M. Marxismo e filosofia da linguagem. São Paulo: Hucitec, 1992.

Estética da criação verbal. São Paulo: Martins Fontes, 1997.

CHARTIER, R. Os desafios da escrita. São Paulo: UNESP, 2002.

FERNANDES, C. R. D. Leitura, literatura infanto-juvenil e educação. Londrina: EDUEL, 2007.

FIJALKOW, J.; FIJALKOW, É. La lecture: idées reçues. Paris: Le Cavalier Bleu, 2003.

FREIRE, P. A importância do ato de ler. São Paulo: Autores Associados: Cortez, 1985.

KOCH, I. V. A inter-ação pela linguagem. 10. ed. 2. reimp. São Paulo: Contexto, 2008.

KOCH, I. V.; ELIAS, V. M. Ler e compreender: os sentidos do texto. São Paulo: Contexto, 2006.

KOSIK, K. Dialética do concreto. 5. ed. Rio de Janeiro: Paz e Terra, 1976.

LAJOLO, M. Do mundo da leitura para a leitura do mundo. 3 ed. São Paulo: Ática, 1997. LOZANO, J; PEÑA-MARIN, C.; ABRIL, G. Análise do discurso: por uma semiótica da interação textual. São Paulo: Littera Mundi, 2002.

MANGUEL, A.. Uma história da leitura. São Paulo: Companhia das Letras, 1997.

MARTINS, M. H. O que é leitura. 19. ed. São Paulo: Brasiliense, 2006.

NEVES, I. C. B. et al. (Org.). Ler e escrever: compromisso de todas as áreas. Porto Alegre: UFRS, 1998.

OKADA, A. PISA 2009: Xangai, na China, lidera ranking de leitura entre estudantes; Brasil está em 53 lugar. São Paulo, 2010. Disponível em: <http://educacao.uol.com.br/ noticias /2010/12/07/pisa-2009-china-lidera-ranking-de-leitura-brasil-esta-esta-em-53. htm>. Acesso em: 06 nov. 2012.

${ }^{14}$ Ver tabela 1. 
RANGEL, M. Dinâmicas de leitura para sala de aula. Petrópolis: Vozes, 1990.

RETRATOS DA LEITURA NO BRASIL. Instituto Pró-Livro - IPL, 2012.

REZENDE, L. A. de. Leitura na graduação. Práxis Educacional, Vitória da Conquista, v. 6, n. 8, p. 73-87, jan./jun. 2010.

Formação de leitores: um caminho possível. In: KARWOSKI, A. M.; GAYDECZKA, B. (Orgs.). Leitura: leitores e bibliotecas no interior do Brasil. União da Vitória: Kaygangue, 2007. p. 33-44.

2009.

RUMELHART, D. E. Schemeta: the building blocks of cognition. In: GUTHRIE, J. T. Comprehension and teaching: research reviews. Newark, Delaware: IRA, 1981. p. 3-26

SAVIANI, D. Pedagogia histórico-crítica: primeiras aproximações. 3. ed. São Paulo: Cortez: Autores Associados, 1992.

SOLÉ, I. Estratégias de leitura. 6. ed. Porto Alegre: Artmed, 1998.

SILVA, E.T. Leitura na escola e na biblioteca: leitura e conscientização. Campinas: Papirus, 1986.

SMITH, Frank. Leitura significativa. 3. ed. Porto Alegre: Artes Médicas, 1999.

YAGUELLO, M. Introdução. In: BAKTHIN, M. Marxismo e filosofia da linguagem. São Paulo: Hucitec, 1992. p. 11-19.

Recebido em 27/05/2012

Versão final recebida em 13/11/2012

Aceito em 19/11/2012 